\title{
Den største trussel mod Erdogan er ham selv
}

\section{Martin Selsøe Sørensen}

Efter ti års succes er Tyrkiet kommet i problemer. Demokratiet går tilbage, udenrigspolitikken ligger i ruiner og de økonomiske udsigter er dystre. Sommerens Gezi-uroligheder har vækket ungdommen fra politisk koma og sat gang i en bevægelse, der kan true den ellers så stærke ministerpræsident - og det har han kun sig selv og sin facon at takke for

Det har længe været klart, at ingen kan vælte Tyrkiets ministerpræsident Recep Tayyip Erdogan. Ikke militæret, ikke domstolene, slet ikke oppositionen, og vælgerne vil ikke. Efter forsommerens omfattende demonstrationer over store dele af Tyrkiet står det stadig ved magt, men med tilføjelsen 'ingen andre end ministerpræsidenten selv'.

Efter mere end ti år ved magten kan han se tilbage på en imponerende forandring af Tyrkiet først og fremmest økonomisk, men også med omfattende politiske reformer, demokratiske fremskridt og etablering af en helt anden selvtillid for en nation med historiske mindreværdskomplekser. Det værk kan ingen udefra tage fra ministerpræsidenten, men nu er han ved selv at styrte det i grus.

\section{Fejllæst oprør}

Ministerpræsidenten fejllæste demonstrationerne og deres årsager, han var arrogant $\mathrm{i}$ sin håndtering $\mathrm{af}$ demonstranterne og samme hånlige bedrevidenhed anvender han i sin håndtering af en særdeles alvorlig økonomisk krise under udvikling i Tyrkiet og i positioneringen af landet i det lige så hastigt udviklende 
og krigsramte Mellemøsten.

Demokrati, udenrigspolitik og $\varnothing$ konomi er tre afgørende fronter for ikke bare Tyrkiet, men for Erdogans værk, og han er ved at tabe sine gevinster og mere til på alle tre fronter.

Demonstrationerne begyndte i slutningen af maj som kun lidt mere end en håndfuld miljøaktivister, der klamrede sig til en klynge træer i Gezi Parken i udkanten af Istanbuls centrale Taksim Plads.

Parken var skummel, ikke hyggelig og generelt overset af istanbul'erne, og få tog sig derfor af regeringens planer om at inddrage træerne og de forhutlede bede til endnu et indkøbscenter.

Dem er der allerede 87 af i Istanbul, 30 mere er under opførelse, og ét fra eller til ophidser ingen. Ikke dengang i hvert fald. I månedsvis havde miljøaktivisterne delt løbesedler ud om truslen foran metrostationen på Taksim, men få tog særlig notits af dem.

"Jeg gik forbi dem hver morgen og tænkte "hvor er det flot af dem, men det nytter ingen ting'", siger en istanbul'er, der først senere blev aktiv i bevægelsen.

Da politiet rykkede ind og fjernede de første aktivister og deres telte, var der derfor ikke grund til at tro, det ville få den store opmærksomhed fra hverken medier eller offentlighed og slet ikke fra udlandet. Det var en fejlslutning.

Politiet gik særdeles hårdhændet til værks med store mængder tåregas og kampuniformer og gik i gang med at brænde aktivisternes ejendele samtidig med, at gravkøer rykkede ind og begyndte at hapse af parken.

En så unødvendigt voldsom indgriben påkaldte sig opmærksomhed, flere demonstranter kom til og snart også en parlamentariker fra det prokurdiske parti BDP, der stillede sig midt foran gravemaskinerne og forlangte at se byggetilladelser. Det standsede for en stund gravearbejdet og politiets aktioner, og endnu flere nysgerrige og forargede borgere og oppositionspolitikere kom til.

Det kapitel af historien om demonstrationerne endte med, at den obsternasige politiker blev ramt af en tåregasgranat og blev kørt på hospitalet i lastrummet af en varevogn, der gjorde det ud for ambulance.

\section{Taksim erobret}

Politiets håndtering af en folkevalgt udløste de demonstrationer, der spredte sig til hele landet og i ugevis belejrede Taksim Pladsen. Undervejs var pladsen i mere end en uge fuldstændig uden for politiets kontrol, etaten var trukket flere kilometer væk og overlod den indre by til befolkningen. Det gik overraskende godt og frem for alt i fordragelighed.

Siden kæmpede politiet sig tilbage med nye enorme mængder tåregas, peberspray og vandkanoner, der 
angiveligt dræbte hundreder af småfugle og måske også er årsag til en usædvanlig lav myggebestand i det centrale Istanbul i år.

Fra at være en protest, der handlede om rydningen af en enkelt park til fordel for et indkøbscenter, blev protesterne hurtigt en platform for alle de grupper i Tyrkiet, der i årtier har været undertrykte, men aldrig tidligere har fundet ud at finde sammen.

Hver gruppe har kun set sine egne problemer, men ikke magtet, overskuet eller turdet forene protesterne imod den samme form for undertrykkelse fra den samme stat.

Før gik for eksempel kurderne på gaden om mandagen, kvinderne om tirsdagen, homo'erne om onsdagen, journalisterne om torsdagen og kemalisterne om fredagen. Hver især med deres egen sag, som det var let for skiftende regeringer at håndtere enkeltvis eller som oftest ignorere.

Med Gezi-protesterne blev det mønster brudt, og det vil forandre tyrkisk politik i de kommende år. Under den politifri uge var Gezi Parken omdannet til et folkemøde, hvor snart sagt hver eneste lille og store gruppe i Tyrkiet var repræsenteret med et telt og en flok ildsjæle. I stedet for blot endeløst at fremføre deres egne synspunkter mødtes de på kryds og tværs og talte sammen, som tyrkere og kurdere med forskellige synspunkter aldrig har talt sammen før.

I Tyrkiet hører man altid til i en gruppe af mennesker, der tænker og lever som en selv, og ofte har man meget lidt eller slet ingen kontakt til anderledes tænkende eller troende, og end ikke noget særlig klart billede af, hvem de er.

"Jeg kender ikke nogen bøsser eller lesbiske, men nu har jeg mødt dem, de holder til lige derovre", sagde 21-årige Elif Özcan under folkemødet, og pegede mod et telt lidt væk.

"Jeg har fået meget større forståelse for deres problemer i Tyrkiet, og så er de virkelig flinke. En af dem henter cigaretter til os".

I et telt med armensk skrift på plakaterne sad Sayaf Tekir, der er medlem af Tyrkiets kristne, armenske mindretal, der normalt holder meget lav profil for at ikke fremprovokere reaktioner fra ultranationalister.

"Mange nationalister har været forbi for at tale med os, og det har været en god oplevelse, både for dem og for os. Der er mange fordomme mod armeniere, så det har været godt at få talt sammen", sagde han.

\section{Öcalan over Taksim}

I et hjørne af parken holdt BDP til under et stort billede af kurderlederen Abdullah Öcalan, der indtil for nylig blev kaldt 'Tyrkiets Osama bin Laden' og 'børnemorder', men som nu forhandler fred med den tyrkiske regering. At hans billede skulle blaf- 
re over Taksim var aldeles utænkeligt før, ikke mindst for Ahmet Metin fra Atatürk-foreningen.

"Jeg har talt med dem fra BDP, det har jeg ikke gjort før. Vi har forskellige ideer, men vi står sammen om protesten mod regeringen", sagde lokalformanden fra sit telt, hvor han sad med to yngre medlemmer.

Over dem på teltdugen dinglede et billede af landsfaderen Mustafa Kemal Atatürk, der grundlagde republikken i 1923. Nu, 90 år senere, er han stadig den Holger Danske, nogle tyrkere søger tryghed hos, når de føler sig truede. Det har de gjort meget de seneste år, og derfor var der rigtig mange Atatürk-billeder på Taksim Pladsen og i Gezi Parken.

Rundt om i parken blafrede alle de andre flag fra grupper, der også gerne ville ses og snakke som tyrkiske feministgrupper, venstreorienterede, højreorienterede, privatskoler, fodboldklubber og mange, mange flere.

\section{Lyset blev tændt}

Protesterne blev ikke kun en udluftningskanal for indestængt vrede og frustration over Erdogans regering og det, der opleves som et voksende autokrati. Protesterne blev også den kontakt, der pludselig tændte lyset i hovedet på en tyrkisk ungdom, der ellers har holdt sig på lang afstand af politik.

For til trods for at Tyrkiet står med store problemer som kvinders lige- stilling, børns rettigheder, mindretalsrettigheder, ytringsfrihed og meget mere, har landet været karakteriseret ved at have en ekstremt apolitisk ungdom. Meget få tyrkere har været aktive i politik, og hvis de har, har det ofte været som formidlere af andres budskaber, men sjældent som aktive deltagere i den politiske debat.

Med Gezi Park-bevægelsen er det forandret.

"Jeg har aldrig deltaget i politik. Jeg er bange for politik, det er farligt. Jeg har set, hvor mange problemer det har skabt for min far, der er aktiv«", sagde Elif Özcan.

Hendes forældre oplevede det blodige militærkup i 1980, og deres børn bliver kaldt den tabte generation, fordi den blodige kamp mellem højre og venstre i Tyrkiet trak sig spor længe efter med drab og forsvindinger og eftertrykkeligt vaccinerede børn og unge mod at nærme sig tyrkisk politik.

"Tidligere tænkte jeg, at vi levede i en dårlig tidsperiode. Jeg følte mig tom inden i og ønskede, at jeg havde levet i 1980, for dengang talte folk politik og skabte resultater. Det gjorde vi ikke", sagde Ece Yumusakkaya, en 17-årig teaterstuderende, der bemandede en bod i Gezi-parken med gratis vandmeloner og vand til demonstranter og forbipasserende.

"Men nu har vi åbnet øjnene. Selv om vi måske taber kampen om parken, så vil vi ikke længere nøjes med 
bare at sove, spise og arbejde. Med protesterne er det forandret, der er blevet tændt et lys".

At der nu er kommet strøm i et ellers slukket kredsløb er fantastisk for Tyrkiet, men det kommer til at tage lidt tid, før det for alvor kommer til at gøre en forskel. De nu politiserede unge er temmelig unge, og der er ikke umiddelbart nogen politiske partier, der kan tilfredsstille deres politiske appetit.

De gamle partier, måske med undtagelse af det pro-kurdiske, er ikke tilstrækkeligt demokratisk anlagte, for belastede af deres fortid og for optagede af fnidder med regeringspartiet til at være attraktive. Men lyset og lysten er tændt, og forståelsen på tværs af grupperne er begyndt at vokse, og det har Tyrkiet ikke oplevet i 30 år.

\section{Skidt på kort sigt}

Selv om der er håb i det lange løb, ser det på kortere sigt ikke så godt ud for Tyrkiet. Sommeren igennem er mindre demonstrationer blevet mødt med nye tåregasangreb og kampklædte betjente.

En 14-årig dreng var under junidemonstrationerne nede i en sidegade for at købe brød for sin mor. Der blev han ramt i hovedet af en tåregasgranat (politiet bruger dem ofte som skyts affyret direkte mod demonstranter). Han lå i juli stadig $\mathrm{i}$ koma, og da hans forældre stillede sig op på Taksim Pladsen for at læse en protesterklæring op, skyndte politiet sig at gasse dem og deres støtter, så de måtte tage flugten.

Sådan er det gået, hver gang nogen har forsøgt at udtrykke kritik af regeringen og politiet, og selv om det efterhånden ikke er overraskende, er det stadig uhyggeligt at se hvor langt myndighederne vil gå blot for at undertrykke synspunkter, de ikke bryder sig om.

Efter urolighederne - der jo vel at mærke først blev uroligheder, da politiet skred ind, indtil da var det fredelige demonstrationer - har regeringen sat gang i en omfattende hævnaktion. Skoleelever har fået at vide, at de ikke kan få statslige stipendier, hvis de råber politiske paroler, og skoleledere har udspurgt elever en for en, om deres lærere har opfordret dem til at deltage i demonstrationer.

Unge eller ældre for den sags skyld må nu heller ikke råbe politiske paroler på fodboldstadions, angiveligt efter fanklubber for alle Istanbuls største fodboldhold var med i Gezi Parken.

\section{Stikkeri}

Fra hospitaler har regeringen forsøgt at finde ud af hvilke læger, der frivilligt behandlede sårede på interimistiske klinikker i Gezi Parken med henblik på at få dem fyret. Stikkeriet går igen helt ned på gadeplan, hvor Erdogan personligt har opfordret folk til at angive hinan- 
den, hvis naboer har deltaget i pot og pande-protester. Hver aften kl. 21 i juni var der i regeringskritiske kvarterer en farlig larm fra potter og pander, der blev banket mod hinanden i protest mod regeringen. I kvarterer nær Taksim blev der også banket, når kampklædte politi nærmede sig i jagten på demonstranter, der flygtede ad sidegader væk fra pladsen.

Hårdest ramt er dog nok en af Tyrkiets store erhvervsfamilier. Det fem-stjernede Divan-hotel klos op ad Taksim blev under protesterne omdannet til lazaret og asyl for sårede og flygtende demonstranter, men blev angrebet af politiet, der fyldte hotellobbyen med tåregas. Andre hoteller nær pladsen gjorde det samme, men myndighederne har tilsyneladende set sig sure på Divan og Koc-konglomeratet, der ejer hotelkæden.

Koc er en af Tyrkiets gamle industrifamilier og er i løbet af sommeren blevet udsat for en omfattende skatterazzia mod dets raffinaderivirksomhed, og et Koc-skibsværft har fået aflyst en stor licitation fra staten, det ellers havde vundet. Den tyrkiske finansminister bedyrer, at der ingen sammenhæng er med Gezi og ingen feje tricks, men det er der næppe nogen, der tror på.

Erdogans eget svar på den folkelige modstand er endnu stærkere modtryk. Han har arrangeret vælgermøder over hele landet og kalder rutinemæssigt demonstranterne for terrorister, forrædere og lakajer for udenlandske interesser. Han og folkene omkring ham taler om konspirationer, der involverer vestlige efterretningstjenester, sågar Lufthansa, Israel og noget han kalder 'rentelobbyen', som er en unavngiven flok, der i skjul arbejder på at presse den tyrkiske rente i vejret. Intet af det har hold i virkeligheden, men hans voksende intolerance over for anderledes tænkende har fået ellers fornuftige folk i hans regering til at klappe i.

Tyrkiske medier har for længst gjort det samme og skilt sig af med mange af de journalister, der ikke kan klappe i, og som sin chefrådgiver har Erdogan hyret en journalist, der mener, at udenlandske magter forsøger at slå Erdogan ihjel med brug af telekinese. Telekinese er at få objekter langt væk til at bevæge sig ved brug af tankens kraft.

Der er altså ingen i Tyrkiet til for alvor at fortælle Erdogan, hvad protesterne handlede om, hvorfor han skal tage dem alvorligt, og at han er ude ad et galt spor med sin heksejagt og stadigt mere rablende konspirationer.

\section{USA trådt i baggrunden}

Alt det kunne Tyrkiets vigtigste partner, USA, sikkert leve med, hvis bare Erdogan var i stand til at levere det, Washington har brug for i Tyrkiets urolige nabolag. Obama-regeringen har for længst gjort det klart, at den 
ikke ønsker at blive involveret i Mellemøsten og hænge fast der, som så mange amerikanske regeringer $f ø r$ den.

I stedet er supermagten trådt $\mathrm{i}$ baggrunden og har overladt scenen til regionale magter som Tyrkiet, Saudi-Arabien, Qatar og ufrivilligt Iran. Hvad angår Tyrkiet var det engang en god ide. Det var dengang, hvor Tyrkiet ville være hele Mellemøstens thehus, stedet hvor regionens stridende parter kom og med tyrkisk hjælp fik løst deres konflikter.

For at styrke sig som konfliktmægler og skabe fred og fremgang i sit nabolag introducerede landet en nu berømt 'nul problemer med naboerne'-politik, som regeringen gik i gang med at føre ud i livet med styrkede bånd til Irak, Iran, kurderne, Syrien og selv Armenien til følge. Tyrkiets styrke er dets blanding af udstrakt demokrati, markedsøkonomi, gode bånd til Vesten og en religiøs bevægelse, der trods modvilje fra militæret er forblevet ved magten i mere end et årti.

Det handlede mere om handel end demokrati, men er siden gået fløjten. Fra tilsyneladende at have gode kort på hånden og i hvert fald have verdens opmærksomhed, er Tyrkiet de seneste måneder gået fra at være en brobygger til at være en brobrænder. I dag har det alvorlige konflikter med Israel, Iran, Irak, Syrien, Egypten og er på kollisionskurs med landene syd for den Persiske Golf over for eksempel Egypten.
Med sin kulturelle, historiske og religiøse baggrund troede den tyrkiske regering, at den kunne trække de arabiske lande ind i sin sfære og påvirke dem i sin egen retning. Midlet var en politik baseret på kultureksport, handelsforbindelser og personlige relationer mellem ledere. Men årene har vist, at Tyrkiet ikke kunne alt det, det sagde det kunne. Dertil var forståelsen og respekten for araberne for overfladisk. Og muligheden for at være USA's forlængede arm er nu spildt.

Det er særligt Tyrkiets håndtering af det arabiske forår, der har demonstreret en udbredt mangel på politisk fingerspidsfornemmelse og en bekymrende tendens til at skabe problemer, hvor det burde finde løsninger.

Få regeringer i verden har været $\mathrm{i}$ så tæt kontakt med amerikanske toppolitikere og toprådgivere som den tyrkiske. Særligt under den syriske opstand har der været tæt på ugentlige kontakter mellem Washington og Ankara. Alligevel har den tyrkiske regering tilsyneladende ikke forstået, at moralske argumenter ikke bider på amerikansk udenrigspolitik.

\section{USA, Tyrkiet, Syrien}

I mere end to år har supermagten holdt sig på lang afstand af konflikten i Syrien og gjort alt for at undgå at blive indblandet. Ikke desto mindre er Tyrkiets politik bygget op om 
en forventning om, at USA vil intervenere og løse konflikten. Det ændrede sig med det kemiske angreb ved Damaskus, men det ændrer ikke ved, at Tyrkiet i to et halvt år spillede på en hest, der end ikke var mødt til start.

I fraværet af udefrakommende løsninger på konflikten har Tyrkiet smidt sin støtte bag hvem som helst, der har udfordret Damaskus, herunder også den al-Qaeda- orienterede Jabhat al-Nusra-gruppe, der opererer i store dele af Syrien. Omfanget af Tyrkiets støtte til gruppen er ukendt, men det har været sigende, at Ankara har kritiseret Vestens afstandtagen til gruppen og selv først i august var ude med kritik af Jabhat al-Nusras drab på syriske civile.

Det må vække bekymring i Washington og EU, og det er ikke det eneste.

Under og efter militærkuppet i Egypten i juli har ministerpræsident Erdogan klart og utvetydigt stillet sig på den afsatte præsident Morsis side. Det har han gjort som den eneste leder i Vesten og i klar konflikt med EU, USA og de arabiske golflande, som Tyrkiet ellers støtter sig til i regionalpolitik. I Morsi ser Erdogan en spejling af sin egen politiske historie som en religiøs politiker, der blev tvunget fra magten af militæret og dets støtter, og han lukker samtidig øjnene for Morsis mange fejl.

Hen over sommeren gik Erdogan så vidt som til at anklage Israel for at stå bag kuppet i Egypten, men mo- dererede udsagnet efter en voldsom reprimande fra Washington. Den tyrkiske ministerpræsident mener nu, at det var 'israelsk mentalitet', der lå bag. Tidligere på året kaldte han zionisme en forbrydelse mod menneskeheden, en udtalelse han trak i land i et interview i Politiken.

$\mathrm{Nu}$ er Tyrkiet ikke det eneste land, der har brændt fingrene på det omskiftelige arabiske forår, men landets regering har gjort ondt værre, end det behøvede. Erdogan raser løbende mod ikke bare sine tidligere venner, de arabiske ledere, men også mod EU, internationale organisationer og 'rentelobbyen'. Udfaldene er så mange og så hyppige, at iagttagere er begyndt at overveje højlydt, om den tyrkiske leder har en skrue løs.

"Erdogan er muligvis demokratisk valgt, men han taler som en paranoid diktator", skrev Financial Times' udenrigschefkommentator Gideon Rachman på Twitter i august.

Jeffrey Goldberg, tidligere Mellemøsten-korrespondent for The New Yorker og klummeskriver på Bloomberg fulgte op:

"Det er på tide at kalde den tyrkiske ministerpræsident Recep Tayyip Erdogan det han er: halvforvirret og snæversynet", skrev han i en klumme.

\section{Hvis bare god økonomi}

Tyrkiske vælgere har ved valg efter valg demonstreret, at de sådan set er 
ligeglade med det meste, hvis bare $ø$ konomien er god, eller de har en rimelig forventning om, at den vil blive bedre. Udenrigspolitik og ytringsfrihed betyder meget lidt for den jævne tyrker, der ikke kommer i berøring med hverken det ene eller det andet i sin dagligdag.

Hvis regeringen lover og i nogen grad leverer job, skoler, veje og lufthavne, er det fra det synspunkt lige meget, om den skaber problemer i udlandet eller fængsler journalister og bedriver heksejagt.

Den største fare for Erdogan er derfor, at hans voksende magtfuldkommenhed og forblindede stædighed også har ledt ham i problemer i økonomien.

I løbet af august er den tyrkiske lira faldet til et rekordlavt niveau over for dollar. Faldet er først og fremmest en reaktion på, at den amerikanske centralbank i efteråret vil stoppe med månedlige opkøb af obligationer for 85 mia. dollar. Det har sat udviklings $ø$ konomier over hele verden under pres, men få er så hårdt ramt som den tyrkiske, og det handler i høj grad om manglende tillid til den tyrkiske regering.

Forsommerens håndtering af Gezi-demonstrationerne, sommerens heksejagt, Tyrkiets involvering i Syrien og det baglænsskridende demokrati gør Tyrkiet til et usikkert eller i bedste fald uforudsigeligt kort at sætte sine penge på.

Den 27. august forsøgte den tyrkiske centralbankdirektør at berolige investorerne, men som et ekko af ministerpræsidentens modvilje undlod han at bruge stigende renter til at beskytte lira'en. I stedet talte han om at vise banken tillid og vente og se, at lira'en vil stige frem mod nytår.

Investorerne har ikke den slags tillid, og talen udløste øjeblikkeligt nye fald. Ikke mindst fordi investorerne fik bekræftet deres frygt for, at nationalbanken er følgagtig over for den tyrkiske regering og ikke selv kan bestemme sin politik.

Det efterlader tyrkisk økonomi i en temmelig dyster position, der i hvert fald er langt fra de seneste års fremgang og givetvis også en trussel mod Erdogans position. Han skyder skylden for problemerne på de finansielle markeder, spekulanter og udlandet $\mathrm{i}$ al almindelighed, og har lidt ret i den forstand, at Tyrkiet jo blot er en brik i den store globale $ø$ konomi. Men han ignorerer, at det er hans og hans regerings opgave at afbøde skadevirkninger og i gode tider polstre landet til dårlige.

Erdogan skulle have grebet ind for længe siden, men havde ikke lyst til at genere vælgerne og risikere at ændre på det billede af sig selv, han har skabt i befolkningen. Nu løber han fra ansvaret, og det er hverken kønt eller i orden.

\section{Erdogan præsident?}

Til næste år er der lokalvalg i Tyrkiet, og i løbet af sommeren skal der 
vælges ny præsident. Det næste parlamentsvalg er i 2015. Det har længe været ventet, at Erdogan vil søge at udvide præsidentens beføjelser efter fransk og amerikansk forbillede og selv stille op til valget. Som Tyrkiets mest populære politiker siden Atatürk er det givet, at han ville vinde. Eller det var det. Nu er det ikke givet længere, og det er heller ikke givet, at han er i stand til at få ændret forfatningen som ønsket.

En forfatningsændring kræver totredjedels flertal i parlamentet. Det har han kun med stemmer fra det pro-kurdiske parti, og de var i foråret så godt som givne på grund af fremskridt i fredsforhandlinger mellem regeringen, repræsentanter for det kurdiske mindretal og oprørsbevægelsen PKK.

En fredsaftale skulle inkludere ligestilling af det kurdiske mindretal med det tyrkiske flertal og ikke mindst inklusion i det tyrkiske samfund og flere frihedsrettigheder. Længe så det godt ud, og parterne forhandlede i tilsyneladende god tro. Men med Gezi og regeringens alt andet end demokratiske håndtering af demonstranterne og deres synspunkter har kurderne mistet troen på, at Erdogan kan eller vil give dem de rettigheder, de drømmer om.

Erdogan fremstår ikke som nogen overbevist demokrat, men som en politiker af den gamle tyrkiske skole, der er vanemanipulerende og ude af stand til at se ud over sin egen snævre bases interesser.

Op til Gezi sagde ledende prokurdiske parlamentarikere, at de ville stemme for hvilken som helst ændring af forfatningen, hvis blot de fik en fredsaftale. Det siger de ikke i dag, og det antages at være særdeles tvivlsomt, at Erdogan får skabt det præsidentembede, han drømmer om.

Et præsidentembede uden nye beføjelser er ikke attraktivt for en mand med Erdogans ambitioner, så spørgsmålet er, hvad han så gør. Hans partis vedtægter tillader ikke, at man stiller op til mere end tre valgperioder. Det kan nok lade sig gøre for ham at få ændret vedtægterne, så han kan fortsætte en fjerde valgperiode med, men spørgsmålet er så, hvad det vil gøre ved partiet.

\section{AKP's fløje}

Gezi-urolighederne har allerede afsløret voksende kløfter mellem en Erdogan-fløj, der snart sagt er med på den værste, og en fløj omkring den nuværende præsident Abdullah Gül og viceministerpræsident Bülent Arinc, der følger udviklingen med voksende ubehag.

Gül er interessant nok mere religiøs end den pragmatiske Erdogan, men har gennem lang tid vist, at hans demokratiske kompas virker, som det skal. Gang på gang har han diskret og uden at komme i offentligt klammeri med Erdogan taget side for mere demokrati, mere gen- 
nemsigtighed og mere diplomati. Han bliver ikke altid lyttet til, men har en solid base, der givetvis er blevet større de seneste måneder.

Han har dog ikke noget, der ligner et flertal bag sig i regeringspartiet, men mindre kan også gøre det. Gezi har skabt røre i tyrkisk politik og det er ikke utænkeligt, at demokratiske kræfter på tværs af alle partier og hidtil apolitiske grupper kan finde sammen på en platform, der handler om mere demokrati, end det AKP i dag står for.

Hvis det skal lykkes at overhale Recep Tayyip Erdogan kræver det, de tyrkiske vælgerpræferencer taget i betragtning, nok først en økonomisk krise, der for alvor vil kaste grus i Erdogans maskineri.

Den kan meget vel være på vej, og hvis det får vælgerne til at flygte og Erdogan til at falde, har han kun sig selv at takke for det.

Martin Selsøe Sørensen er korrespondent for Politiken i Tyrkiet og medlem af Udenrigs' redaktionskomite.

Kommentarerne fra demonstranter $i$ Gezi Parken er citeret fra skribentens egne artikler i Politiken. 